\title{
The Forest in African Traditional Thought and Practice: An Ecophilosophical Discourse
}

\author{
Mark Omorovie Ikeke \\ Department of Religious Studies and Philosophy, Delta State University, Abraka, Nigeria \\ Email: ikeke7@yahoo.com
}

Received January $14^{\text {th }}, 2013$; revised February $16^{\text {th }}, 2013$; accepted February $28^{\text {th }}, 2013$

\begin{abstract}
Copyright (c) 2013 Mark Omorovie Ikeke. This is an open access article distributed under the Creative Commons Attribution License, which permits unrestricted use, distribution, and reproduction in any medium, provided the original work is properly cited.
\end{abstract}

\begin{abstract}
In traditional African thought which is still prevalent in many places in Africa, despite the onslaught of globalization and the attendant consequences of colonialism, the forest is held and revered to be a sacred entity and in most cases the habitation of supra-human forces. Apart from clearing for cultivation and human residence, the forest was generally preserved and protected from endangerment. Today, in most places especially in urban Africa this is no longer the case. A colonialist ideology that commoditises the forest has taken root and some no longer see anything wrong in wanton destruction of forest land and degradation of forests. This work uses a critical method to interpret the African concept of the forest, propose reclaiming aspects of the African concept of the forest. The work finds and concludes that there are viable gems in the African heritage that can help to combat climate change and the environmental crisis.
\end{abstract}

Keywords: Africa; Forest; Traditional Thoughts; Ecophilosophy; Environmental Crisis

\section{Introduction}

A key area of the environment is forest. Forests hold great value in every local community and in the global world. Without forests, trees, shrubs, and other plants, which are part of every forest, the only thing you will see before you when you look ahead of you will be bare sand, stones, mountains, and a natural landscape without the beauty of forests and trees. A landscape without forests will greatly harm human health as one of the essential elements that take carbon dioxide from the atmosphere and produces oxygen for human survival is lacking. The forests are not only important to human life, but also important for the survival of other non-human lives and species that depend on the forest environment for survival and flourishing. The forests should be looked upon not simply for its utilitarian value but for its intrinsic ontological value. The forest has value in itself, not simply because of its value for human persons. In African metaphysical ontology, the intrinsic value of the forests is rooted in its pantheistic-psychic foundation, which implies that the divine active force and spirit of the creator pervade all creation. It is this that gives value to all things, not simply on their utility.

The prime task of this work is to critically appraise the understanding of the forest in traditional African ontology. In order to do this properly, it is important to clarify and analyze some basic concepts such as forests, African traditional thought and practices, and ecophilosophical.

\section{Conceptual Clarifications and Analyses}

The Webster's Dictionary of the English language (2004) defines forest as "a large area of land covered with trees and brush growing thickly” (p. 358). Though there can be a small forest, merely having some trees scattered or even in one location does not make a forest. The trees should be generally spread over a large area and covering the land or soil. For The Chambers Dictionary (1994), a forest is a "large uncultivated tract of land covered with trees and undergrowth” (p. 654). Invariably a forest can only be found on land or swampy ground as in a mangrove forest. With regard to Africa which has a tropical rain forest, its forest as Anizoba (2005) indicates it is in the low latitudes with heavy and regular rainfall and high temperatures. The African forest is filled with thousands of species ranging from trees, shrubs, parasites, animals, humans, other living organisms, and a rich landscape. The forest is significantly valuable for Africa as other regions that have forests. Forest provides food resources, wood for various human projects, habitation for humans and other animals, recreation, regulate temperature, help ameliorate climate change, and prevent erosion. Besides its economic importance, pharmaceutical relevance, and the great sociocultural significance that it holds for indigenous peoples, Murck (2005) shows that forest provides environmental services such as stabilizing the soil, replenishing the soil's nutrients, helps in the hydrologic cycle, holding humidity, harboring extensive reserve of biodiversity, and regulating climate change.

On its own and as a word, ecophilosophical is derived from the short form of ecology, eco, and the adjectival form of the word philosophy, philosophical. Ecology as defined by Blackburn (2005) is "the science which investigates the interacting systems of biological organisms” (p. 109). This interacting system of biological organisms is what is technically called ecosystem. Ecology in a sense is the study of ecosystems. For 
the avoidance of doubt, Rajagopalan (2011) notes that: “an ecosystem is a community of living organisms (population of species) interacting with one another and with its non-living physical and chemical environment. "The interactions are such as to perpetuate the community and to retain a large degree of stability under varying conditions” (p. 23). It is important to note here that ecology is a science though the findings and data from that scientific field could be reflected upon by disciplines in the humanities and other fields, for from the perspective of inter-disciplinarity no discipline should be totally cut off from other disciplines. Emphasizing the scientific nature of ecology is highlighted by Mackenzie, Ball, \& Virdee (1998) when they argue that:

Ecology is a purely scientific discipline which aims to understand the relationships between organisms and their wider environment. Like any science, the outcome of ecological studies does not dictate ethical or political actions. It is important to make this distinction because the environmental movement has endowed the word ecology with political connotations. It is right that ecology should inform politics, but as a student of ecology it is imperative to consider ecological research from rigorous scientific viewpoint (p. 4).

The findings of ecological research have implications for every other field of human study such as philosophy. It is the methods and processes of applying critical thinking in a rational manner to the issues of ecology or interactions of all life forms and other elements in the environment that is considered ecophilosophical. Ecophilosophical is the philosophy of ecology, philosophy being understood as critical reflection on being; and other realities in the cosmos. It probes into the "whyness" and essence of things and in its ethical form proposes norms of behavior in relationship with all other realities. Appiah (2003) opines that the root of philosophy is "to give a general and systematic account of our thought and experience, one that is developed critically, in the light of evidence and argument” (p. 378). Philosophy is interested in raising and probing into the difficult questions and perplexities of things that other disciplines normally do not ask. With regard to ecophilosophy, this is done with the aim of moving beyond mere scientific data about ecosystems to prescribing ethical ideas on what ought to be human relationship with ecosystems in order to accentuate a sustainable planet.

The ecophilosophical perspective taken in this work is to indicate that the aim here is not simply to do ethnophilosophy or merely narrate African traditional beliefs on forests. African traditional ideas and beliefs about the forest essentially before it became diluted with colonial and contemporary ideas about forests are the concern here. Traditional thought is not totally stagnant, but essentially before it was impacted by colonial and western forces it was to a certain degree homogenous within that particular cultural community as it has come through consensus or tested experience. Cultural beliefs about the forests were not half-hazard or irrational. They come from indigenous pragmatic experience of the environment. They may not make sense to a modern scientific mind but they helped people to navigate through their natural and cultural world. It is important then to appraise and evaluate African idea of the forest, interrogating it in a critical manner, with the goal of proposing that all in traditional thought about the forests is not obsolete or decadent. There are ideas that could be mined from traditional thought that can help in ameliorating the ecological crisis, while being sensitive to the hostile and perverse aspects of traditional thoughts. Those aspects such as patriarchy, slavery, female genital mutilation, etc need to be confronted. For instance there are forests in Africa that women were not permitted to enter, whereas males even those of a younger age than such women are permitted to enter. There are trees or fruits that women are not permitted to touch or to harvest, but men are allowed to touch them. Those who died mysterious and shameful death, even when it is not their faults could only be buried in the socalled evil forest. In traditional times twin babies were thrown into the evil forest. In order to get healing cream or life elixir young men were sent on dangerous and difficult journeys into distant forests, just to save the life of the son of the king or great elder. This same privilege was not accorded to ordinary members of the community. The children of people who were not part of royalty could die and it really did not matter.

These points are mentioned to show that there is no romanticization of every African idea about the forest. Yet in the midst of these limitations there were also ideas about the forest that helped in environmental protection.

\section{The Forest in African Traditional Thought}

The African understanding of the forest cannot be separated from the African cosmological view of reality. Life is seen as one integrated bond and interrelated web. There is no pure and absolute dualism in the African worldview. All life-spirits, humans, animals, plants, trees, oceans, rocks, etc come from God. They depend on the creator God for their existence and sustenance. In the African understanding all life is infused by the active and dynamic life force of the creator. The Malawian scholar Sindima (1990) is right to opine that African perception of the cosmos is life-centered; life is the essential characteristic of the universe, a universe in which all beings are inter-connected. This idea is corroborated by Ehusani (1991), when he affirms the reality that the African sees the universe as one in which humans are at the center, that the universe is pervaded by a sacred mystical order that should not be unduly disturbed. The sustaining presence of God keeps all things in being. Ferguson (2010) expresses this wisdom of Africa thus: "the universe is viewed as God's creation and is filled with the divine presence” (p. 29). Using the Yoruba culture as an example, Maguire (2000) citing Jacob Olupona states that African culture is ecologically friendly for all plants, animals, and human persons are carriers of the same divine energy and kinship, one family.

Though all life is infused by the vital life force that does not imply all life is homogenous. The African world was framed in a hierarchy of being; a hierarchy which can be misused and misapplied to promote patriarchy, sexism, and other oppressive evils prevalent in some places in Africa. The hierarchy should be seen as that of mutualism and commensalism. In the hierarchy each entity was there to enhance and enrich the other. Human persons were to use the elements of creation to moderately sustain themselves while at the same time conserve them. Human persons were to tap the higher forces above them to strengthen their life force through religious rites and rituals.

The trees, plants, animals, and other organisms which make up the forest were infused with spirits. In Africa, the forest is not simply the trees. It is inclusive of all that inhibits and lives 
in the forest. In the piece, Creation in African Thought (n.d) the author affirms rightly that:

To many African peoples trees and forests had special significance. The Ngombe live in very dense forest and refer to God as: "The everlasting One of the forest", "the One who clears the forest", "the One who began the forest", while a number of peoples set aside sacred groves for sacrifices, offerings or prayers ... A number of peoples feared the spirits of the forest and of the water ... From several parts of Africa come accounts of trees which refused to be moved, even by modern machinery designed for the task. These trees are believed to have magical power.

That is why the discussion on forest management and other uses of the forest should not simply be limited to economic concerns. The wellbeing and concerns of the humans, and other non-human elements in the forest should be taken into consideration. The forest should be looked to not only for its wood and timber provision, but also for how it can be preserved to promote all life and the sustainability of the ecosystems. This is why what happens to medicinal plants, other organisms, biodiversity in the process of harvesting for wood should be taken into consideration.

In traditional times, African people lived and dwelled in the midst of the forest. The forest like mother earth was seen as a source of life. African people respected and reverenced the plants in the forest, for as Burnham (2000) puts it, the plants were the "most spiritual and mysterious of all life forms" (p. 35). In great historical saga and epics, brave African warriors had to travel through seven hills and rivers in search of a life water or cream that would bring deliverance and salvation to their troubled communities or to save the royal lineage. Down in the heart of the forest was the paradise that held the "tree of life." Only the courageous could venture to the heart of paradise. Surrounding the forest of paradise were many other forests in which African people lived their lives and these forests were accessible to all in the community.

This shows that there were different types of forests in Africa. All forest did not carry the same homogenous power. The same forest may have different areas that were perceived with different imaginations. In some forests there were places that were accessible to all; beyond a certain place it was accessible only to the chief priest or medicine man. Some forests were considered to be evil forests for they were inhabited by malevolent forces and people who died mysterious or untimely death were thrown into them. Evil forests as well as forests that carried the charm of life or life elixir where special sacred religious rituals were performed were generally preserved and were not to be destroyed. Not far away from African villages and towns were sacred groves inhabited by sacred trees and abode of ancestral guardian spirits. These groves were centers of biodiversity. Sacred groves as other forms of forest were inhabited by various animals, plants species and organisms. African hunters rarely carried their hunting to the above named forests. The view in some quarters that see African forests either as homogenous or undifferentiated is not tenable. It runs against the experience of this author who grew up in an African rural setting and is still experiencing African rural life.

The spirits that permeate or possess forests or trees are not the same. Some forests are possessed by good spirits while some are possessed with evil spirits. Adogbo (2000) discussing the spirit world of African peoples argues that:

The Urhobo believe that the forest groves in the area are the homes of various kinds of land-spirits. The spirits in the forests may be classified into two categories, viz, primordial and malignant spirits. The primordial spirits are the ones so created by God, while the malignant spirits are the souls of victims of irregular deaths, such as drowning, suicide, death as a result of thunder, small-pox, and death during pregnancy or during child-birth. The corpses of victims of these irregular deaths are not accorded the normal funeral rites and, therefore, cannot join the ancestors in the spirit world, called erivwin (p. 114).

\section{Adogbo (2000) argues further that:}

The malignant spirits ... also inhabit the forest groves in Urhoboland. These are spirits of irregular deaths which are not accorded the appropriate funeral rites. They are buried in bad-bush called awharode in urhobo language. No farming is done in the awharode and they are avoided, especially on Urhobo sacred day called Edewo. The people believe that the spirits manifest more on Edewo. As a result, important rituals, such as the burial of males, communal redressive rituals and assemblies of igbe adherents, are preformed on this day of the native week of four days (p. 116).

What all these testify to is the reality that the African forest is not homogenous. The term, awharode means a bush or forest that is higher or bigger. Though it is possessed by evil spirits they are considered to carry higher energy and force. As for the good forests inhabited by good spirits, they were to be used with care and prudence and human persons are not to engage in wanton destruction of the forests. As for the forest inhabited by malignant spirits, they were to be totally left uninhabited, uncultivated and wild. The only thing that can be done in them is to use them as the burial place of persons who died in a mysterious manner. While a data-driven scientific mindset may disagree with this classification of forests, and argue that they are based on superstitions, the reality remains that the forests that were left untouched continued to play their vital ecological role in adverting climate change, deforestation, soil erosion, and degradation of the landscape.

Peterson (2009) has revealed that the use of the forest among forest-dwellers in central Africa moved beyond utilitarian purposes as they had a mutual relationship with the forest. They were able to innovate in the midst of change and natural disaster. They knew how to adjust their lives to the changing patterns of the forest. He writes that:

If one year the forests gives only a little of the preferred asali honey, they know where to look for the less sweet but also good apiso. If hunting proves poor in one locale, switching camp to a new area was not difficult. In other words, nature and humans interrelate with some degree of flexibility and slack. Unlike western biocentrists who tend to view humans as victims under the heavy hand of nature as taskmasters, Central Africans see nature as offering them some freedom of choice rather forcing their fate upon them. The experience of Central Africans provide us with a lesson. It affirms that although we cannot do with nature whatever we please, neither does nature leave us 
freedomless. Instead there exist the opportunity and...the responsibility for us to play a creative role in shaping the future of the natural and social evolutionary process. We are co-creators, not simply victims of natural deterministic forces (p. 172).

While it is true that you can speak of an African worldview for most African cultures have a lot in common, it is also true that they have some peculiarities. The beliefs about trees and forests in Africa are subject to variations. The point is that there was various use of the forest in Africa based on localities. The particular kind of forest that was considered to be an evil forest may not be an evil forest in another locality. A type of forest that was considered unreachable in one locality may be easily navigated by forest-dwellers in another locality. Whatever the perception of forest, it helped the people in that particular community to adjust and adapt to the comic forces in that forest. African beliefs and perceptions about the forests no matter how you understand it, helped in ecological preservation and inhibited climate change either consciously or unconsciously. Trees and forests were left uncultivated and allowed to flourish thereby preserving the lungs of life that provided oxygen and that absorbed carbon dioxide from the environment. Compare this with the so-called enlightened colonial mindset and fanatical Christianity that have little or no value for sacred trees and forests. Trees are felled without taking into consideration that such act will cause climate change on a local level and deplete the atmosphere of oxygen that human persons need. It should be realized that from every perspective such as physical health, mental health, environment, aesthetics, etc. every tree that is felled, not to speak of forests that are destroyed, the earth is impoverished and a great deal of species is lost. African forests such as the mangrove forests and rain forests are rich in biodiversity, medicinal resources, spiritual recreation opportunities, arenas for education and training into manhood/womanhood, etc. Every loss of an African forest is a great loss.

It is imperative to continue to insist that the value of African forests goes beyond utilitarian purposes. This can be adduced from the value of plants and trees that constitute the forest. Writing on tree spirits in Africa, Burnham (2000) enunciates that: "plants are the essence of life. They sustain us all, but their significance to Africans is far deeper. Their importance lies in their closeness to creation and hence their purity ... 'In the divine leaves we are able to find understanding of ourselves and dreams"” (p. 36). In Haitian Voudou, which could be considered an African ancestrally derived religious culture, there is a deep reverence for trees and forest in accordance with its West African inspired background. As Rey (2005) relates, spirits and ancestors inhabit nature, trees inclusive. Sprits and ancestors have trees as their most precious homes. Explicating this point further, Rey (2008) indicates that: "The dead are likewise deeply enmeshed in nature and conceived of as residing either under the ground, across the water, or in the forest. Trees and the forest, though increasingly scarce in the impoverished nation, have thus always featured prominently in Haitian Voudou's rich symbolism and mythology" (p. 1659). He points out that the significance of trees in Voudou arises from the fact that it is the source of the sacred drum, the Voudou priest's sacred rattle, source of divine approach. Certain species of trees are deeply revered and are planted to demarcate shrines. With reference to Benin Republic in West Africa, Rey (2008) shows further that the spirits of ancestors resides in ceiba pentenda, a most venerated tree in the Caribbean. What Rey argues about the Afro-Caribbean countries is equally true of mainland Africa. He argues that: "however pervasive is this spirit of reverence for trees in Haiti, it has been overwhelmed by the nation's grueling poverty and overpopulation ... the result is desertification and a litany of related ecological problems. Thanks to Voudou, at least, in some of the countries (sic) most desertified regions there are at least a few mapou trees...” (p. 1659). This is equally true of many African countries. Many urban cities would have been totally bereft of trees if not for the sacred groves that are still in existence in those cities. While not debating the veracity of the beliefs of traditional religions, the fact remains they deserve credit for being a source that has preserved trees and forests for present day Africa. There is need to reclaim the language for deep reverence for trees, without equating the trees to the cosmic creator. According to Taringa (2006), the Shona people: "believe that particular trees, forests and mountain forests are imbued with spirits. They develop, like in the case of animals, taboos around the cutting and destruction of certain trees, shrubs and forests” (p. 208). Also in Shona beliefs there were sacred forests and mountain forests, the burial sites of chiefs, the habitation of guardian spirits and the ancestors. These forests were called rambamtewa which means woodland that could not be cut. It was morally wrong to cut woods in these places and firewood and other resources needed by human persons have to be fetched from other places. The animals and plants in these sacred forests were protected from extinction (Tanringa, 2006).

It ought to be noted that despite the fact that there were evil forests in Africa, the evil forests were not the creation of the Creator. Evil forests are the result of various malevolent spirits that wrestle against human destiny and want to thwart the efforts of the benevolent creator. Various myths in Africa spell out the origin of evil. It is not within the scope of this piece to examine that. The reality of the goodness of the forest is corroborated by the predominant belief of the Pygmy of the Central African forest. In the website Traditional African Religion (2012), it is affirmed of the Pygmies that:

The dominant Pygmy belief is in the god of the forest, who is benevolent, and to whom men pay as much respect as they do to their own parents. There are popular songs of joy and praise which have as motif the simple theme that the forest is good. The forest-god is in the trees or the river or waiting silently near his worshipper, and a basket of food is the sign that he has been invoked. There are religious societies, particularly male, which function in celebration of the forest-god and are active at festivals of puberty for boys and girls, with ritual dancing and feasting.

Equally important to state about the African concept of the forest is that every area of African life and culture is casted in a paradigm of communalism. The African communal attitude to life affected all elements of life. Tangwa (2006) interprets the African outlook as eco-bio-communitarianism which implies "recognition and acceptance of interdependence and peaceful co-existence between earth, plants, animals, and humans" (p. 389). The communal outlook also implies as Tangwa (2006) argues that all of life is seen as one, and the distinction between plants, animals, and inanimate elements is flexible and slim. This does not mean there is no difference between plants and 
animals, and other elements in the world, but no matter the difference all beings and realities in the cosmos intermingle and interrelate. Tangwa (2006) argues further that among his own Nso' people of the Bamenda in Cameroon this difference is recognized but it does not give human persons any special privilege or unlimited right to subdue, dominate, conquer and exploit nature, rather human persons are to live with nature in a spirit of co-existence and friendship making moderate use of the things of nature.

This also affects the African understanding of the forests and trees. The forests are a communal heritage from the ancestors. It is held in trust by the community under the direction of the town elders and chiefs for the wellbeing of the entire community. There are no personal or private forests in traditional Africa. You cannot own the forests. Not even the community owns the forests. This being the case you are not at liberty to do what you desire with the forests. There were customary laws in the forms of taboos that governed the human relationship with the forests. There were totemic and sacred trees in the forest that were not to be touched or felled. In most places in traditional Africa, it was prohibited to cut down young and infantile plants and trees. Those trees belong to the entire community are expressed very well in the Shona belief that all large trees belong to the ancestral spirits. It is important to note that the very land or earth on which forests and trees grow and depend on is a communal heritage and so all things on the land are part of it. Jacob Olupona as cited by Maguire (2000) opines accurately that: "Land...belongs to the ancestors. The eldest in the clan had the right to use and protect the land, but it was a sacred trust, not an absolute right. It was a kind of communal ownership, and it certainly did not involve the right to abuse the land. The reverence that was felt for the ancestors was also felt for the land. This is a beautiful example of we-self culture" (p. 54). The same reverence that is given to the land must be accorded all that the land carries or produces, including plants, herbs, and trees.

\section{Concluding Reflections}

The call for reclaiming viable aspects of traditional thoughts on forests should not be equated to romanticism with the past. Taringa (2009) cites Tomalin who argues that in most literature on religion and the environment there is a romanticising of the past in which people perceive there was an eco-golden age that existed in the indigenous past in which people of non-industrial societies lived in deep friendliness with the earth. The fact is that there is no culture or groups of people that can totally separate or cut themselves off from their past. The past can serve as a teacher and even as a midwife of new culture. The African traditional past is not totally useless. If there are things that inspire and can contribute to environmental protection, they need to be harvested and re-cultivated. It will be dishonest to affirm that some aspects of the African past cannot serve environmental protection. So also it will be dishonest to claim that every aspect of the African past can serve environmental preservation. In the African past there were harmful practices that degraded the earth, so also there were practices that protected the earth. The challenge before African scholars is to retrieve what is viable and still relevant and discard what is obsolete.

Traditional beliefs about trees and forests have enabled much more forests, sacred groves, and trees to still be standing; thus enabling Africans to experience much more the benefits from the values in trees and forests. Without traditional beliefs about sacred trees and forests, perhaps the onslaught of colonialism, its attendant consequences, and fanatical Christianity that destroys trees and forests in the name of converting people to Christ, would have been more devastating and there would have been fewer trees standing, and the effect of the ecological crisis in Africa would have been worse. As noted earlier this piece is not an endorsement of every form of beliefs and practices associated with trees and forests. Imagine if much of the African beliefs and practices mentioned above were to be revitalized, refined and reconceptualised and enhanced with further scientific data it will greatly help in ecological preservation.

It should be concluded that it is imperative to rethink the wholesome condemnation of African cultural beliefs and practices. When this is critically done it would be seen that there are viable gems that Africa can bring to the marketplace of globalization that can help to combat climate change and environmental crisis.

\section{REFERENCES}

Adogbo, M. P. (2000). The spirit world of African peoples. In S. U. Erivwo, \& M. Adogbo (Eds.), Contemporary essays in the study of religions: Volume one (pp. 104-123). Lagos: Fairs and Exhibitions Nigeria Limited.

Anizoba, M. A. (2005). Exploitation and management of natural resources: A sustainable approach. Awka: Scoa Heritage Systems.

Appiah, K. A. (2003). Thinking it through: An introduction to contemporary philosophy. Oxford: Oxford University Press.

Blackburn, S. (2005). Oxford dictionary of philosophy. Oxford: Oxford University Press.

Burnham, O. (2000). African wisdom. London: Judy Piatkus.

Creation in African thought. (n.d).

http://www.afrikaworld.net/afrel/creation-in-atr.htm

Ehusani, G. O. (1991). An Afro-Christian vision (Ozovehe): Towards a more humanized world. Lanham, MD: University Press of America.

Ferguson, D. S. (2010). Exploring the spirituality of the world religions. London: Continuum.

Mackenzie, A., Ball, A. S., \& Virdee, S. R. (1998). Instant notes in ecology. Oxford: Bios Scientific Publishers.

Maguire, D. C. (2000). Sacred energies: When the world's religions sit down to talk about the future of human life and the plight of this planet. Minneapolis: Fortress Press.

Murck, B. (2005). Environmental science: A self-teaching guide. Hoboken, NJ: John Wiley \& Sons.

Peterson, R. B. (2004). Central African voices on the human-enevironment relationship. In R. S. Gottlieb (Ed.), This sacred earth: Religion, nature, environment, 2nd edition (pp. 168-174). New York: Routledge.

Rajagopalan, R. (2011). Environmental studies: From crisis to cure. Oxford: Oxford University Press.

Rey, T. (2008). Trees in Haitian Vodou. In B. Taylor (Ed.), Encyclopaedia of religion and nature: Volume II (pp. 1658-1659). New York: Continuum.

Sindima, H. (1990). Community of life: Ecological theology in African perspective. In W. Eakin, C. Birch, \& J. McDaniel (Eds.), Liberating life: Contemporary approaches to ecological theology. Maryknoll, NY: Orbis Books.

Tangwa, G. B. (2006). Some African reflections on biomedical and environmental ethics. In K. Wiredu (Ed.), A companion to African Philosophy (pp. 387-395). Malden, MA: Blackwell Publishing.

Taringa, N. (2006). How environmental is African traditional religion? Exchange, 35, 191-214.

Traditional African Religion. (2012). http://www.meta-religion.com/World_Religions/Ancient_religions/A frica/traditional_africa.htm\#ixzz1tckroN7n 


\section{O. IKEKE}

The Chambers Dictionary (1993). The Chambers dictionary. Edinburgh: Chambers Harrap Publishers.

The New Webster's Dictionary of the English Language (2004). The
New Webster's dictionary of the English language. New York: Lexicon Publications. 